Research, part of a Special Feature on Sustainable Land-Use Practices in Mountain Regions: Integrative Analysis of Ecosystem Dynamics Under Global Change, Social-Economic Impacts, and Policy Implications

\title{
A Contextual Analysis of Land-Use and Vegetation Changes in Two Wooded Pastures in the Swiss Jura Mountains
}

\author{
$\underline{\text { Joël Chételat }}^{1}$, Michael Kalbermatten $^{2}$, Kathryn S.M. Lannas $^{2}$, Thomas Spiegelberger $^{2,3}, \underline{\text { Jean-Bruno Wettstein }}^{4}, \underline{\text { Francois }}^{\text {Gillet }}$ \\ Gillet $^{2,5}$, Alexander Peringer $^{2,6}$ and Alexandre Buttler ${ }^{2,7}$
}

ABSTRACT. This study examines the effects of land-use policies and natural events on the evolution of two wooded pastures in the Jura Mountains in Switzerland between 1934 and 2000. The socioeconomic context and the local conditions were seen as major driving forces influencing land management practices which in turn redefined land-use policies. We studied the dynamics of the Jura Mountains' wooded pastures, combining a thorough knowledge of the historic context with aerial image analysis. Besides pointing out general milestones in the evolution of Swiss land policy, we compiled chronicles on the management for both study sites on the basis of archives and interviews. Aerial images taken at time intervals of approximately 15 years were chosen to identify land-cover changes. The method used to analyze them relied on a structural classification of phytocoenoses, thus allowing the determination of four categories of tree-cover densities ranging from unwooded pastures to ungrazed forest. We reported overall aerial changes for each tree density class as well as spatial transitions from one category to another. The combination of spatial statistics with qualitative data depicting the evolution of the historic context gives a better understanding of the land-use changes and their rationale. The most important changes in tree density occurred during World War II and resulted in a more open landscape. The intensive use of wooded pastures during the war was the consequence of a high demand for wood and food resources. Postwar protectionist regulations, agricultural subsidies, and technical improvements maintained considerable pressure on wooded pastures. Storms and drought episodes further exacerbated this process in some areas. The trend then reversed from the 1970s onwards because of the limitations put on milk production and the falling price of wood. This resulted in a more extensive use of pastures, leading to tree encroachment. However, remote sites were more impacted than pastures closer to inhabited areas, which exhibited a trend towards more segregation between grassland and densely wooded pastures. With both extensification and segregation of land use, the complex vegetation mosaic and the landscape diversity that characterize wooded pastures are threatened but still offer good economic opportunities that call for differentiated management strategies.

Key Words: land-cover changes; land-use changes; land-use dynamics; land-use policy; landscape dynamics; pasture management; pasture-woodlands; silvopastoral system; woodland management; Jura Mountains, Switzerland

\section{INTRODUCTION}

Wooded pastures are typical landscapes in the Jura Mountains in Switzerland, shaped by traditional farming and logging activities at altitudes of 900 to $1400 \mathrm{~m}$ elevation (Buttler et al. 2009). Stemming from the close interaction between natural and human systems they have evolved over several centuries, and are emblematic cultural landscapes (Antrop 1997). Mountain pastures provide resources that are complementary to those available in lowland areas for agriculture. Wood is also exploited from these pastures for timber and energy production.

Pasture management has been studied in depth over the years (Heady 1949, Stoddart 1960, Roath and Krueger 1982, Ganskopp 2001). Variation in grazing intensities resulting in spatially heterogeneous habitats is influenced by a variety of factors such as environmental conditions, animal performance, and management methods (Owens et al. 1991;
Lyons and Machen 2001, 2002). Depending on the context, land management decisions may then drive pastures towards either a more intensive use with a consequent lack of tree regeneration or, on the contrary, towards a more extensive use leading to tree encroachment where cattle pressure is low, and eventually to land abandonment (Gallandat et al. 1995).

Land management practices are influenced by local factors as well as more global forces (Kronert et al. 1999). Besides the natural conditions in which land use takes place, the socioeconomic opportunities and constraints-notably changes in agricultural and forest policy_impact farmers' and foresters' decisions on land management (Lambin et al. 2001, Huber et al. 2013). Thus, land use responds to changes driven by biophysical and socioeconomic systems and in turn influences them (Turner and Meyer 1994, Aspinall and Hill 2008). Synergetic factors of various kinds act at different scales in land development (Lambin and Geist 2006).

\footnotetext{
${ }^{1}$ MicroGIS Foundation for Spatial Analysis (MFSA), Switzerland, ${ }^{2}$ Laboratory of Ecological Systems (ECOS), Ecole Polytechnique Fédérale de Lausanne (EPFL), Switzerland, ${ }^{3}$ Mountain Ecosystems Research Unit, National Research Institute of Science and Technology for Environment and Agriculture (IRSTEA), France, ${ }^{4}$ Bureau d'agronomie, Switzerland, ${ }^{5}$ Chrono-environnement, Université de Franche-Comté/CNRS, France, ${ }^{6}$ Institute of Landscape Planning and Ecology (ILPOE), University of Stuttgart, Germany, ${ }^{7}$ Swiss Federal Institute for Forest, Snow and Landscape Research (WSL), Switzerland
} 
Understanding the contexts and influences on land-use change is therefore of primary importance (Aspinall and Hill 2008) to guarantee sustainable agricultural and forestry activities, and to preserve a characteristic landscape with a rich biodiversity (Antrop 2004, Eichhorn et al. 2006).

The analysis of land-use dynamics is often limited to observing changes in the biophysical environment without addressing spatial transformations (Verburg et al. 2004), and to relating them to the socioeconomic context. A spatially explicit approach based on geographic information sciences and integrating not only natural but also socioeconomic, political, technological, and cultural factors is therefore needed to produce more explanatory results (Krausmann et al. 2003, Taillefumier and Piégay 2003). In addition, land-use transition analysis is generally limited to broad spatial occupancy changes (Plieninger and Schaar 2008). More subtle transformations within a land-cover category are rarely addressed though they have significant implications on the ecological functions, production potential, and symbolic value of landscapes (Plieninger and Schaar 2008). These implications are particularly true for wooded pastures characterized by a complex mosaic of herbage with various tree densities. Thus, a transdisciplinary approach has to be tasked with documenting the contemporary evolution of mountain pastures, and with relating the observable spatial changes in landscape structure to the environmental context, the land policy framework, and the management practices.

\section{Contextual milestones in managing wooded pasture}

During the last century, the Swiss rural landscape was largely shaped by wartime and postwar policies as well as improvements brought about by the agricultural revolution. Until the twentieth century, simple open pasture systems were generally the norm for cattle breeding in mountainous areas. Following the Federal Forest Law of 1902 (Loi fédérale concernant la haute surveillance de la Confédération sur la police des forêts 1902) and its aim to maintain the forest cover, wood was only moderately exploited until the World War II, thus leading to aging forest stands (Schuler 2008). Whilst the exploitation of wood increased to satisfy demands during the war, cattle breeding declined in favor of cropping areas for the national food security plan (Wahlen Plan (Tanner 2011)). Mountainous pastures unsuitable for growing crops were, however, still used for breeding cattle.

The postwar years showed an upturn in breeding production, which did not decline until the end of the 1970s (Fig. 1). As an outcome of the war, the Federal Agricultural Law of 1952 (Loi fédérale sur l'amélioration de l'agriculture 1952) established price and market guarantees in order to sustain agricultural production (Stalder 2009). Federal export subsidies made provision for the excess produced from the ongoing intensification process to be fully used. Growth in productivity and yield was made possible thanks to greater milk production, milk preserving techniques such as pasteurization, the achievement of heavier slaughter weights, and methods for faster fattening of the cattle (Moser and Brodbeck 2007, Moser 2010). Furthermore, the influences of mechanization, fertilizers and improvements in management structures became evident. Rationalization also favored a differentiated management of pastures and forest leading to land-use segregation and a more binary landscape (Rieben 1957).

Fig. 1. Evolution index of agricultural indicators in Switzerland between 1935 and 1998 (source: Swiss Federal Statistical Office).

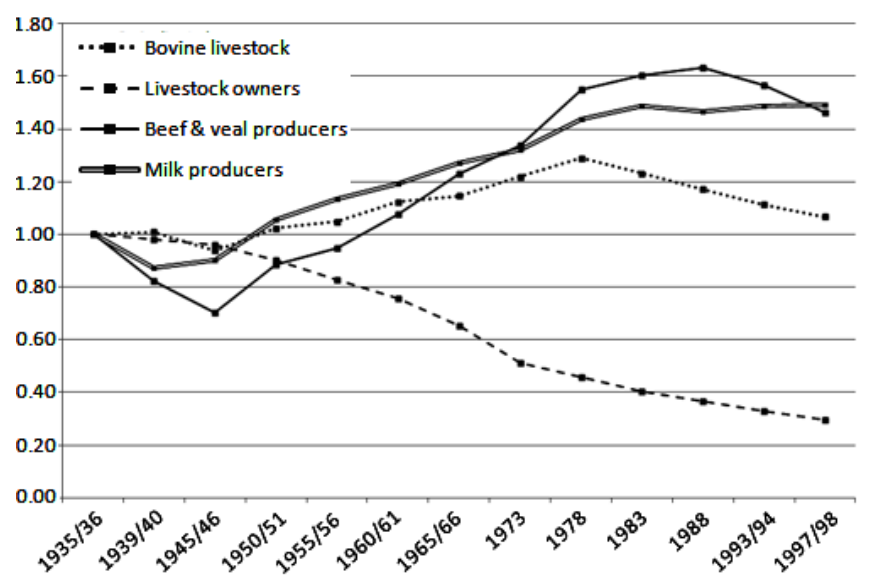

By 1959, direct payments had been introduced to motivate mountain farmers to stop producing milk. This resulted in a change in agricultural practices, encouraging the breeding of calves with suckling cows or heifers. A further development in 1977 was the introduction of milk quotas, limitations on cattle units per farm, and even subsidies for herd reduction (Brodbeck 2009, Stalder 2009). At the same time, wood prices started to decrease until forest expenditures exceeded sales income from the mid-1980s onwards (Service des forêts, de la faune et de la nature 2011). As a result, some forest maintenance activities were left out as an economy measure. Concurrently, the wood economy was severely impacted by the effects of two storms, Vivian in 1990 and Lothar in 1999, and is still slowly recovering (Schuler 2008).

The milk price paid to producers decreased linearly between 1990 and 2000 until it reached the late 1970s price and then stabilized, which corresponded with the number of milk producers (Fig. 1). Simultaneously, the Bovine Spongiform Encephalopathy (BSE) epidemic impacted the production of bovine meat in Switzerland (Moser 2010). In 1998, a new Federal Agricultural Law (Loi fédérale sur l'agriculture 1998) was adopted following the General Agreement on Tariffs and Trade (GATT) international negotiations. It abolished price 
guarantees and export subsidies and introduced direct payments for environmental services as well as summering contributions based on a Livestock Unit (LU)/100 days equivalent rather than surface compensation.

\section{Objective}

The objective of this study is to document changes in land-use intensity of two wooded pastures in the Swiss Jura Mountains and analyze them in light of land policy change. Transformations are studied using tree density as a convenient proxy to quantify the landscape dynamics. Although tree species composition may have also been an interesting variable to take into account, identifying different species is tricky when using black and white aerial images. This aspect was addressed by modeling work which is presented elsewhere (Peringer et al. 2013). A scale of four different degrees of afforestation was computed for five different periods (1934, 1954, 1968, 1985, and 2000) from a series of multitemporal aerial images that are seen as a central resource for land transformation analysis. Besides computing overall areal changes for each tree density class, we also report spatial transitions from one category to another. The documentation of wooded pasture dynamics was complemented by GIS data describing management structures and by pastoral chronicles providing insights on the social and economic systems based on material from archives and interviews. The combination of spatial statistics with qualitative data depicting the evolution of the historic context brings a better understanding of the land-use change and its rationale. This study shows how individual management practices relate to higher-level decisions that consider local environmental conditions and consequently how they impact the landscape. Results derived from the two specific case studies inform on general factors governing land-use dynamics and pave the way for possible future developments (Peringer et al. 2013, Huber et al. 2013).

\section{Study site}

Two wooded pastures located in the Swiss Jura Mountains of Canton de Vaud were analyzed (Fig. 2). They were chosen because they differ in land management, although they were both included as summering areas until recently, meaning that they are away from the main farm and can legally be used only to breed cattle during summer (art. 9 Ordonnance sur la terminologie agricole, OTerm, 910.91, 7. December 1998).

The first site is located near the village of Bullet $\left(46^{\circ} 50^{\prime} 25^{\prime \prime}\right.$ $\left.\mathrm{N}, 6^{\circ} 33^{\prime} 12^{\prime \prime} \mathrm{E}\right)$ at approximately $1225 \mathrm{~m}$ elevation. It includes the two farms of Les Planets and Les Cluds covering an area of 97.5 ha (Fig. 3). It has a mean monthly temperature of $13.5^{\circ}$ $\mathrm{C}$ and a mean monthly precipitation of $119 \mathrm{~mm}$ (August mean values between 1950 and 2000, WorldClim - Global Climate Data 2005). It is situated on a gentle southeast-facing slope. The landscape is fairly open with relatively few scattered trees. The area was used as a common pasture by farmers living in the neighborhood until the 1980s. It was then divided into sections and put up for rent. In 2000, the summering pasture of Les Planets was converted into a Utilized Agricultural Area (UAA), meaning that the area may be used all year to grow fodder or crops.

Fig. 2. Map of Switzerland showing the location of the study regions in the Jura Mountains.

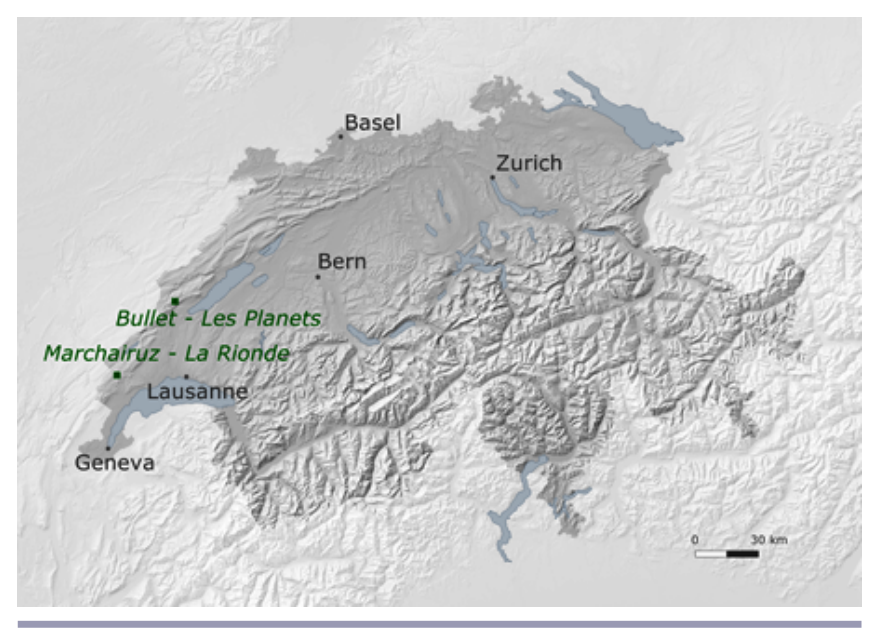

The second site, the farm Rionde Dessus, is located in the upper part of the municipality of Bassins $\left(46^{\circ} 31^{\prime} 12^{\prime \prime} \mathrm{N}, 6^{\circ}\right.$ $11^{\prime} 42^{\prime \prime}$ E). It covers an area of 117.9 ha near the Marchairuz Pass at approximately $1307 \mathrm{~m}$ elevation (Fig. 4). It has a mean monthly temperature of $13.3^{\circ} \mathrm{C}$ and a mean monthly precipitation of $110 \mathrm{~mm}$ (August mean values between 1950 and 2000, WorldClim 2005). It is situated above a southwestnortheast anticlinal valley away from built-up areas. Trees typically grow on the calcareous ridges whereas more productive pastures occupy lower stands characterized by deep marly colluvial soils. The landscape is dominated by sparsely wooded pastures with a high proportion of individual trees and small groups of trees. The utilized area contains two buildings, one being the farmhouse which hosts the farmer who rents the pasture and the other being a grass shelter/storage barn. The first divisions of the pasture into paddocks date to the 1930s and underwent several changes until 2000.

\section{METHODS}

\section{Data on land-use and landscape changes}

Aerial images were obtained from the Swiss Federal Office of Topography (swisstopo) to study the land cover dynamics in the pasture-woodlands. Given the availability of historical photographs, a time interval of approximately 15 years was chosen to chart the evolution. This is considered sufficient given that changes are rather slow in mountainous and forested areas. Images from various dates were then selected, considering the time step and data availability for the study regions. The available older pictures date back to 1934; then 
Fig. 3. Aerial images of the pastures in Bullet showing their spatial organization, including the farms of Les Rasses, Les Planets, and Les Cluds (source: swisstopo).

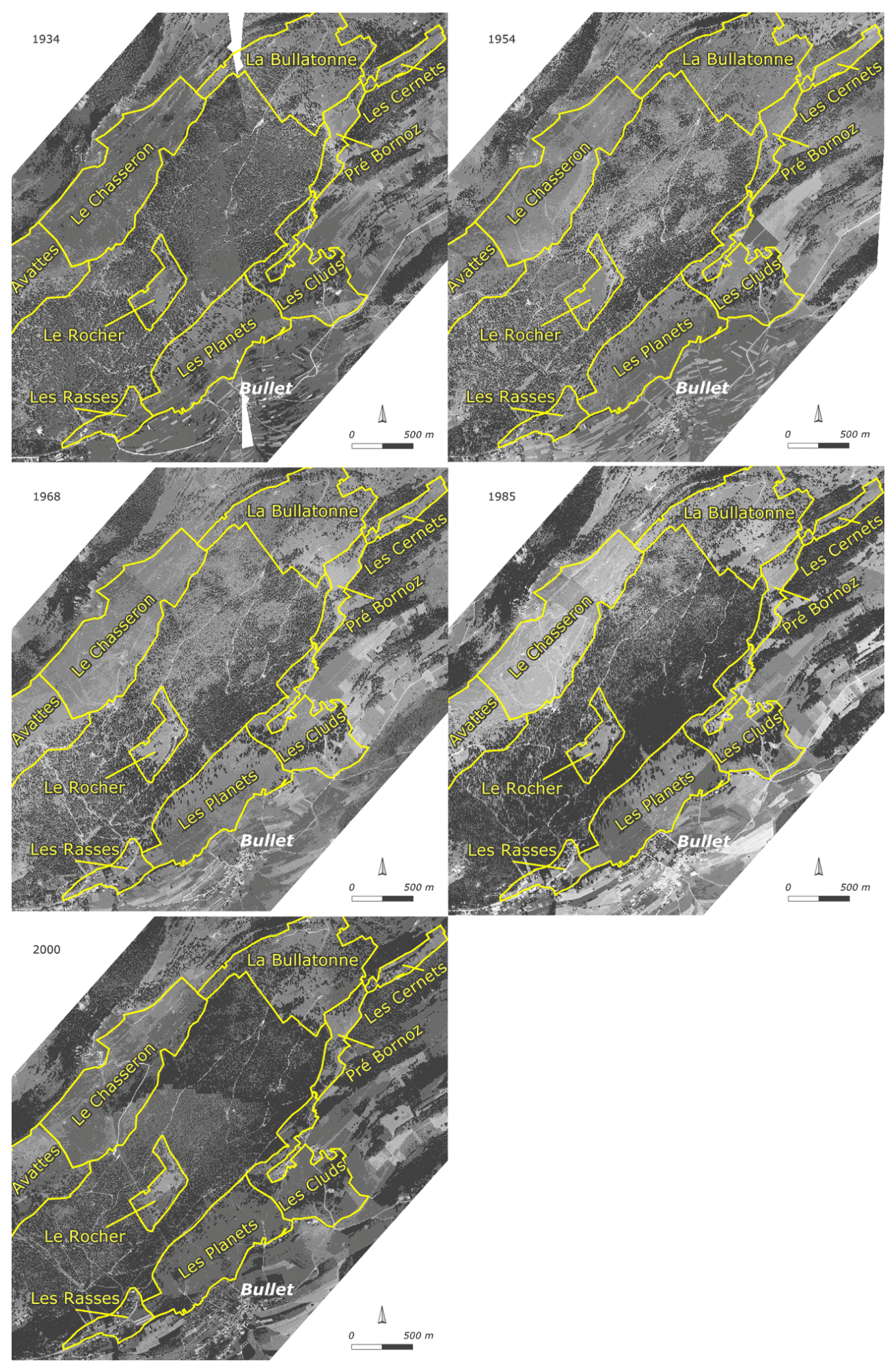


Fig. 4. Aerial images of the pastures near Marchairuz showing their spatial organization, including the farms of Rionde Dessus and Rionde Dessous (source: swisstopo).

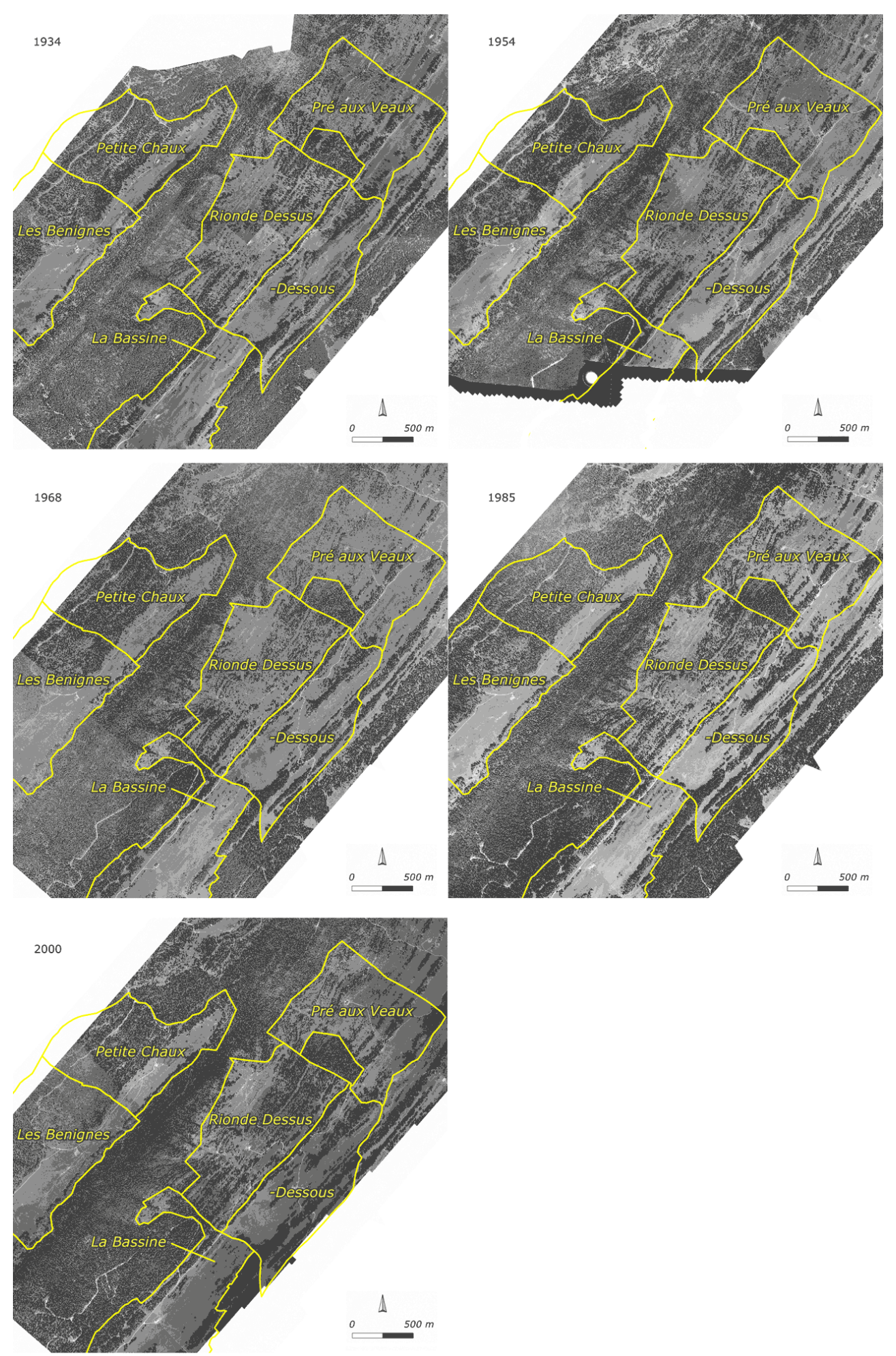


Table 1. List of the documents consulted for the project.

\begin{tabular}{ll}
\hline \hline Bullet - Les Planets & Marchairuz - La Rionde \\
\hline $\begin{array}{l}\text { Forest Management Plans: 1928, 1950, 1960, 1975, 1992 } \\
\text { (Commune de Bullet 1928). }\end{array}$ & $\begin{array}{l}\text { Forest Management Plan: 1916. Revised 1928-29 and 1935-36 } \\
\text { (Commune de Marchissy 1916, Commune de Le Vaud 1916). }\end{array}$ \\
$\begin{array}{l}\text { Pastoral Management Plan: 1964 (Commune de Bullet 1964, } \\
\text { Office Fédéral de l'Agriculture 1962-1974). }\end{array}$ & $\begin{array}{l}\text { Land Register for Mountain Agriculture: 1972 (Office Fédéral de } \\
\text { l'Agriculture 1972, Office Fédéral de l'Agriculture 1962-1974). }\end{array}$ \\
$\begin{array}{l}\text { Land Register for Mountain Agriculture: 1974 (Office Fédéral de } \\
\text { l'Agriculture 1974). }\end{array}$ & \\
$\begin{array}{l}\text { Silvopastoral Management Plan: } 1983 \text { (Commune de Bullet } \\
\text { 1983). }\end{array}$ & \\
\hline
\end{tabular}

images from 1954, 1968, 1985, and finally 2000 were selected. They were all scanned at a pixel size of $50 \mathrm{~cm}$ and then georeferenced and orthorectified to guarantee scale accuracy, in order to compute spatial statistics and allow comparison over time. Aerial images from 2000 were the only ones in color so they were converted into grayscale images to be compliant with the approach. A total of 18 images was collected for the Marchairuz region and 16 for Bullet.

Macro data available at the national level were collected to identify the general driving forces and depict their influence on wooded pasture management during the last century. Information about land policy regulations and reforms came from official online sources such as the Classified Compilation of Federal Legislation (http://www.admin.ch/ch/e/rs/rs.html) and the Historical Dictionary of Switzerland (HDS) (http:// www.hls-dhs-dss.ch/index.php). Forest and agricultural statistics describing the evolution of jobs, exploited areas, production, subsidies, and prices come from the Swiss Federal Statistical Office (http://www.bfs.admin.ch/bfs/portal/en/ index.html) and the Federation of Swiss Milk Producers (http://www.swissmilk.ch/fr.html). In addition, critical views of the socioeconomic evolution were found in the literature (Moser and Brodbeck 2007, Moser 2010).

At a more regional scale, the only comprehensive survey documenting the wooded pasture organization and production in Switzerland is the Land Register for Mountain Agriculture (Office Fédéral de l'Agriculture 1972, 1974). Two snapshots are available for our time span: 1974 for Bullet and 1972 for Bassins. They display data on the grazed area, livestock types, cattle loads, grazing periods, number of paddocks/divisions, and application of fertilizers, as well as possible recommendations for improvements.

Complementary data were collected at the local and landowner level through inquiries at the Forest Service district offices and the public archives. Interestingly, old pastoral and forest management plans give valuable insights into planned and realized interventions and past land management approaches and visions (see documents listed in Table 1). The pastoral and silvopastoral management plans document how the wooded pastures were used in 1964 and 1983 in Bullet and in 1980 in Marchairuz. They notably include data on water points, fence demarcations, and fodder potential, and propose ameliorations in terms of livestock type, cattle load, pasture subdivisions, rotation systems, and fertilization.

In addition, the pasture of La Rionde was included in a Forest Management Plan in 1916 which was revised in 1928 and 1935 (Commune de Marchissy 1916, Commune de Le Vaud 1916). The plan identifies wooded areas, woodcuts, growing stocks, number of stems according to size categories, logging potential, and other strategic measures. The 1998 Forest Management Plan also gives valuable details on the evolution of the growing stocks from the 1950s onwards.

The documents collected for the study are listed in Table 1.

Given the relative scarcity of official documents about wooded pastures, especially before the 1960s, interviews were held with local people from the agricultural and forestry community in order to supplement the analysis with narrative data (Table 2). Semistructured individual interviews were conducted to fill in the gaps in the regional silvopastoral history. At first, the current situation was documented by the persons in charge in the considered and neighboring wooded pastures. Thirteen farmers aged 30 to 60 described their pastures, detailing the fence demarcations, fodder potential, livestock types, cattle loads, grazing periods, infrastructures (buildings, roads, and water supplies), and fertilizing methods. The two current Forest Officers did the same for forest management and wood exploitation. Firstly, using the present situation as a reference state, all of these people were then asked to outline any event and change in land management and practice that they were aware of. Secondly, three retired people aged 70 to 80 who had worked in the studied wooded pastures and witnessed their evolution over the last 60 years were questioned. Again, the present situation served as a starting point to pinpoint differences with their recollections of past situations and events. All interviewees were asked to give detailed statements as well as document and localize them where possible in order to spatialize all significant information in a GIS. In this regard, the historical aerial images were used as prompts and to 
Table 2. List of the persons interviewed for the project.

\begin{tabular}{ll}
\hline \hline Bullet - Les Planets & Marchairuz - - La Rionde \\
\hline $\begin{array}{l}\text { Current officer of the Forest Office, 7th and 10th forestry district, Ste- } \\
\text { Croix. }\end{array}$ & $\begin{array}{l}\text { Current officer of the Forest Office, 14th forestry district, St- } \\
\text { George. } \\
\text { Former forester of the } 7^{\text {th }} \text { forestry district. }\end{array}$ \\
$\begin{array}{l}\text { Two current farmers in the study area, one being a mountain } \\
\text { restaurant owner, and both having succeeded their fathers. } \\
\text { fine current farmers in the study area, eight having succeeded their } \\
\text { Twors. }\end{array}$ & \begin{tabular}{l} 
Twotired farmers in the study area, one being a former mayor. \\
\hline
\end{tabular}
\end{tabular}

determine where events took place. Each interview lasted approximately between 1 and 2 hours.

\section{Analysis of aerial images and integration of pasture chronicles}

The option chosen to analyze the dynamics of pasturewoodland landscapes was to develop a methodology for computing and comparing tree cover through time. As the aerial images were of varying quality, none of them having the same orientation, focal, contrast, or shading parameters, the method had to be simple enough to be applied consistently to all pictures for both sites.

The principle consisted of determining a local minimum in the grayscale tones distribution, which corresponded to the separation between forest and pasture pixel values. The algorithm can be detailed in four steps:

i) The distribution of image pixel values was computed for each photograph and a local minimum was determined. In most of the analyzed images, the frequency distribution histogram was composed of two peaks (local maxima), representing forest (dark pixels) and pasture (bright pixels). The local minimum between these two peaks defines the contrast threshold $T$.

ii) Knowing the threshold and standard deviation of the image, a sigmoid curve was then computed between $T \pm \sigma$ (Equation 1). This enables the classification of each pixel yi over an interval [0,1], 0 representing the black tones and 1 the white tones. These curves are often applied to image processing, in particular in histogram equalization (Parker 1997, Braun and Fairchild 1999).

$$
g_{1}\left(y_{i}\right)=\left\{\begin{array}{cl}
0 & , y_{i}<T-\sigma \\
\frac{1}{1+e^{(-0.7 \cdot n)}} & , y_{i} \in[T \pm \sigma] \\
1 & , y_{i}>T+\sigma
\end{array}\right.
$$

with:

$$
n=20 \cdot\left(\frac{y_{i}-(T-\sigma)}{2 \sigma}\right)-10
$$

iii) A 25-m resolution grid was superposed onto the reclassified image and a grayscale mean tone value $m$ was computed for all the pixels contained in each grid cell. Each mean value was then attributed a category according to a structural classification of phytocoenoses in pasturewoodland landscapes (Gallandat et al. 1995, Gillet and Gallandat 1996). Types are conventionally expressed as fourdigit numbers with the first digit corresponding to tree-cover rate categories: type 1000 for unwooded pasture with a tree cover below 1\%; type 2000 for sparsely wooded pasture with a tree cover ranging between $1 \%$ and $20 \%$, including mostly scattered trees or bushes; type 3000 for densely wooded pasture with a tree cover ranging between $20 \%$ and $70 \%$, in which trees are mostly clustered; and type 4000 for grazed forest with a tree cover higher than $70 \%$.

iv) Finally, the thresholds $(L 1, L 2$, and $L 3)$ defined by the structural categories (Equation 3) were visually adjusted for each analyzed image in order to better reflect the local reality. In order to mitigate variations in the interpretation of these categories as much as possible, one of the ecologists who developed the Patubois classification did the threshold adjustments. Validation was undertaken by digitizing all wooded patches in two test zones and by computing a tree cover ratio using the same $25-\mathrm{m}$ resolution grid. The comparison with the expert approach gave a calculated error ranging between 15 and $20 \%$. It only concerned misclassifications between neighboring categories.

$$
g_{2}(\bar{m})= \begin{cases}1000 & , \bar{m} \geq L_{1} \\ 2000 & , L_{1}>\bar{m} \geq L_{2} \\ 3000 & , L_{2}>\bar{m} \geq L_{3} \\ 4000 & , \bar{m}<L_{3}\end{cases}
$$

The overall proportion of all four tree density categories was computed for each survey date in both study sites in order to show the relative evolution. Trend lines for each category are displayed in a graph. Local changes are represented in four evolution maps. Differences in structural classes were computed for each period showing where extensification and intensification processes occurred in space. Negative values indicate a move towards a denser tree cover whereas positive values indicate a move towards a decrease in tree cover. For 
Fig. 5. Evolution in management structures and in tree-cover categories between 1934 and 2000 in Bullet.

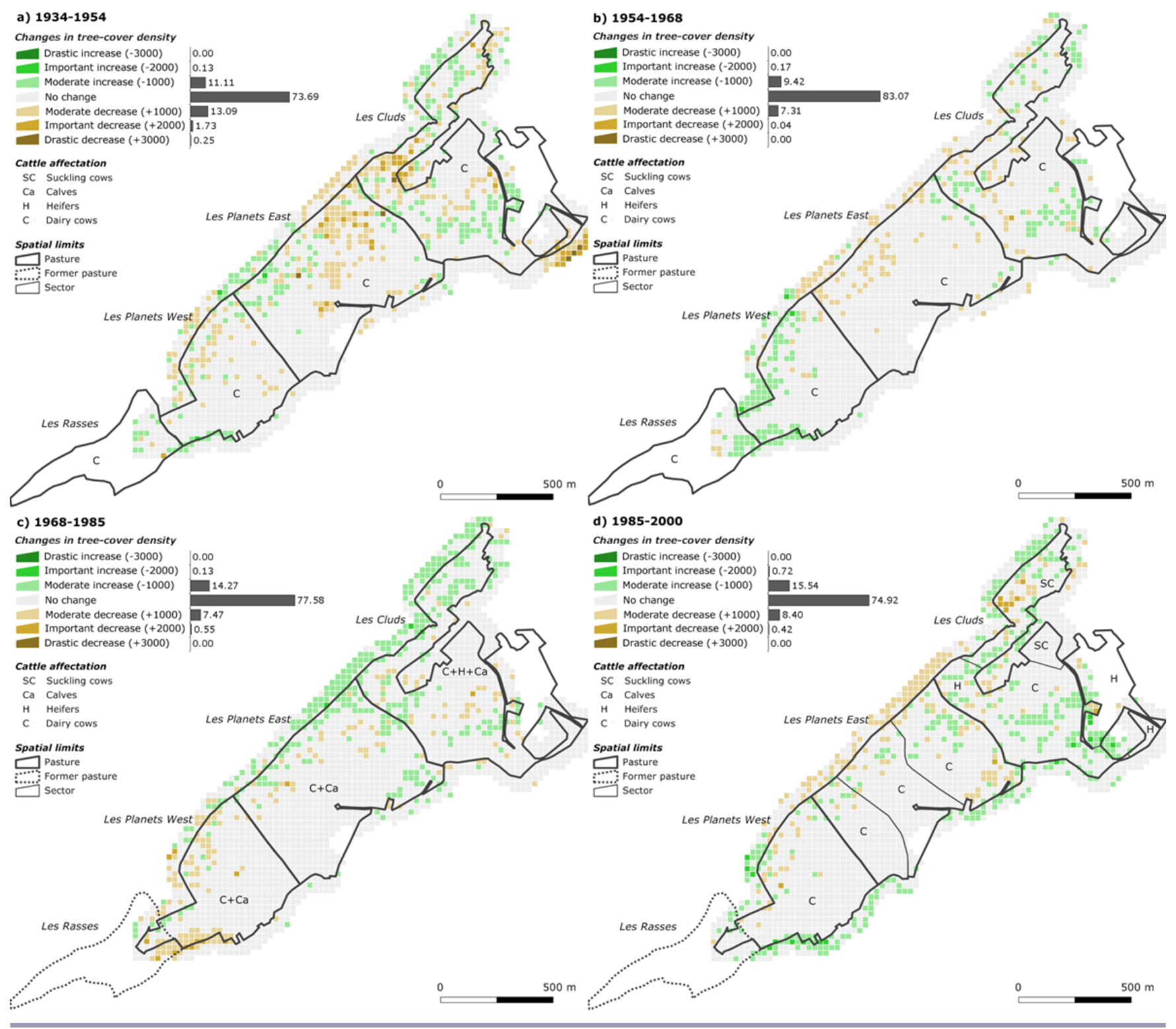

instance, a value of -3000 means a drastic change from unwooded pasture (1000) to grazed forest (4000). Zero values mean no change.

The integration of land-cover change information and wooded pasture chronicles relies on the analysis of the reciprocal influence of the observed changes in the aerial images and the manifold driving forces that were identified. For each observation period, occurrences of natural events, policy moves, management shifts, and concrete practice changes were listed and their potential effects deducted from the spatial transformations in the evolution maps. In return, policy, management, and practice adaptations were also analyzed in the light of land-use changes. Of course, not all management measures have a direct impact on land use and even those which alter spatial parameters do so in different ways. Similarly, land transformations may lead to redefinitions of land management strategies at different levels and pace.

\section{RESULTS}

\section{Bullet}

Pasture chronicles

The whole mountain above Bullet was originally a free-range pasture. During the 1930s, Les Planets was managed as a single 
pasture together with Les Rasses and Les Cluds with no divisions between them. This common pasture, called Communal de Bullet, was used during summer. The cattle herd, consisting of only dairy cows, grazed there during the day and was returned to the village at night, as witnessed by one of the interviewees who was a local cowhand in his teenage years. The milk was used for the production of cheese. In the middle of summer, the cattle crossed the Communal de Bullet twice daily to reach higher pastures like Les Avattes and La Bullatonne. Due to the many farmers using the pasture at different times, it is extremely difficult to determine how many animals constantly grazed on it. However, the cattle pressure was most probably high. Because Les Planets could be accessed by two parallel paths from the village as interviewees recall, the decision was taken in the early 1940s to divide Les Planets pasture into two sectors (Les Planets West and East), each one associated with a cheese-making facility. From then on, the pasture was separated from Les Rasses and Les Cluds by a fence (Fig. 5).

In 1964, a management plan was designed for 100 dairy cows $(100 \mathrm{LU})$ and water was to be supplied to 12 paddocks in Les Planets, but this was never realized. According to the Land Register for Mountain Agriculture of 1974 (Office Fédéral de l'Agriculture 1974), the pasture was instead divided into four paddocks allowing the summering of a total of 100 dairy cows with 30 complementary calves (106 LU). Les Cluds was divided in three paddocks to contain 36 dairy cows, 51 heifers, and 29 calves (62 LU). Given the high tree density observed in Les Cluds, a revision of the silvopastoral management plan was required by an expert. At the same time, the pasture of Les Rasses was completely abandoned with only a small area saved and annexed to Les Planets (Fig. 5). With the new silvopastoral management plan of 1983 (Commune de Bullet 1983), Les Planets ceased to be a common pasture and was divided into four sectors. Each of them was then rented to a different farmer, with the size of the sectors allocated in proportion to the size of their herds. Similarly, Les Cluds was split into three sectors and rented to three farmers breeding dairy cows. Since then, two of the herds were replaced, one by heifers and the other by suckling cows. The third sector was used by both dairy cows and heifers.

\section{Aerial image analysis}

The pasture of Les Planets showed an overall tendency towards emphasized land-use segregation between pasture and forest (Fig. 6). Sparsely wooded pastures (2000) decreased linearly from 1934 until the year 2000, only at a slightly slower pace between 1985 and 2000. This category lost more than half of its initial area. Sparsely wooded pastures (2000) were either replaced by unwooded pastures (1000) (especially between 1934 and 1954) or wooded areas (3000 and 4000). Unwooded pastures (1000) kept on expanding until 1985 and then slightly decreased and stabilized at around $65 \%$ of the total area. Densely wooded pastures (3000) continuously gained ground.
By the year 2000, their proportion became greater than that of wooded pastures (2000).

Fig. 6. Evolution of tree-cover categories between 1934 and 2000 in Bullet and in Marchairuz.

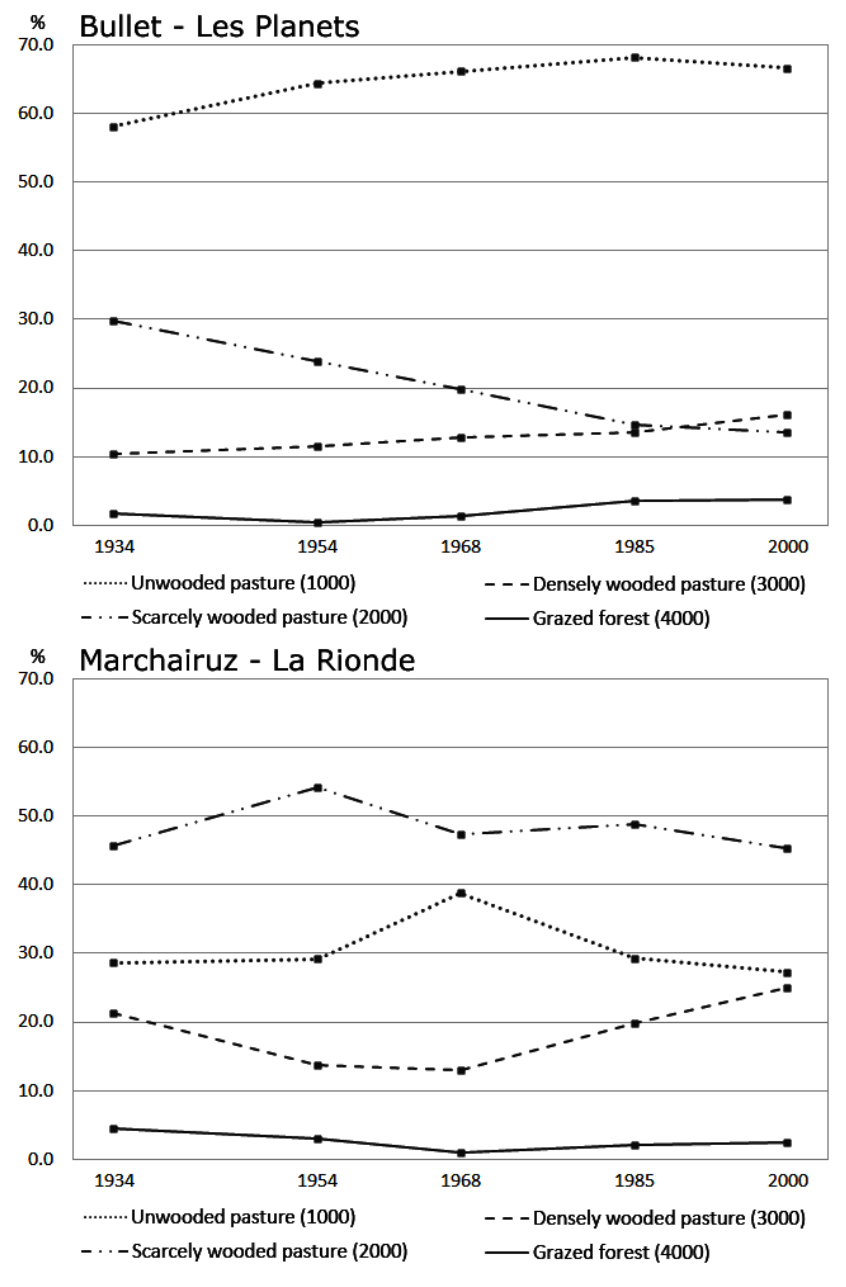

The 1934 to 1954 evolution map (Fig. 5) confirms the previously observed land-use segregation trend. The western sector of Les Planets exhibited a dominant, though rather moderate, decrease in tree cover reflecting an intensification process, whereas the other pastures showed a more contrasted evolution. Signs of intensification and of extensification appear in the eastern sector of Les Planets and in Les Cluds. An increase in tree density is visible in the neighborhood of already existing wooded areas (see Fig. 3), especially along the borders. These local transformations are quite important, not only showing a shift from one tree-cover category to the next (e.g., 3000 to 2000), but also implying changes with a higher amplitude (e.g., 3000 to 1000).

The following periods showed an overall increase in tree cover, but Les Cluds was the only pasture to display a steady 
Fig. 7. Evolution in management structures and in tree-cover categories between 1934 and 2000 in Marchairuz.

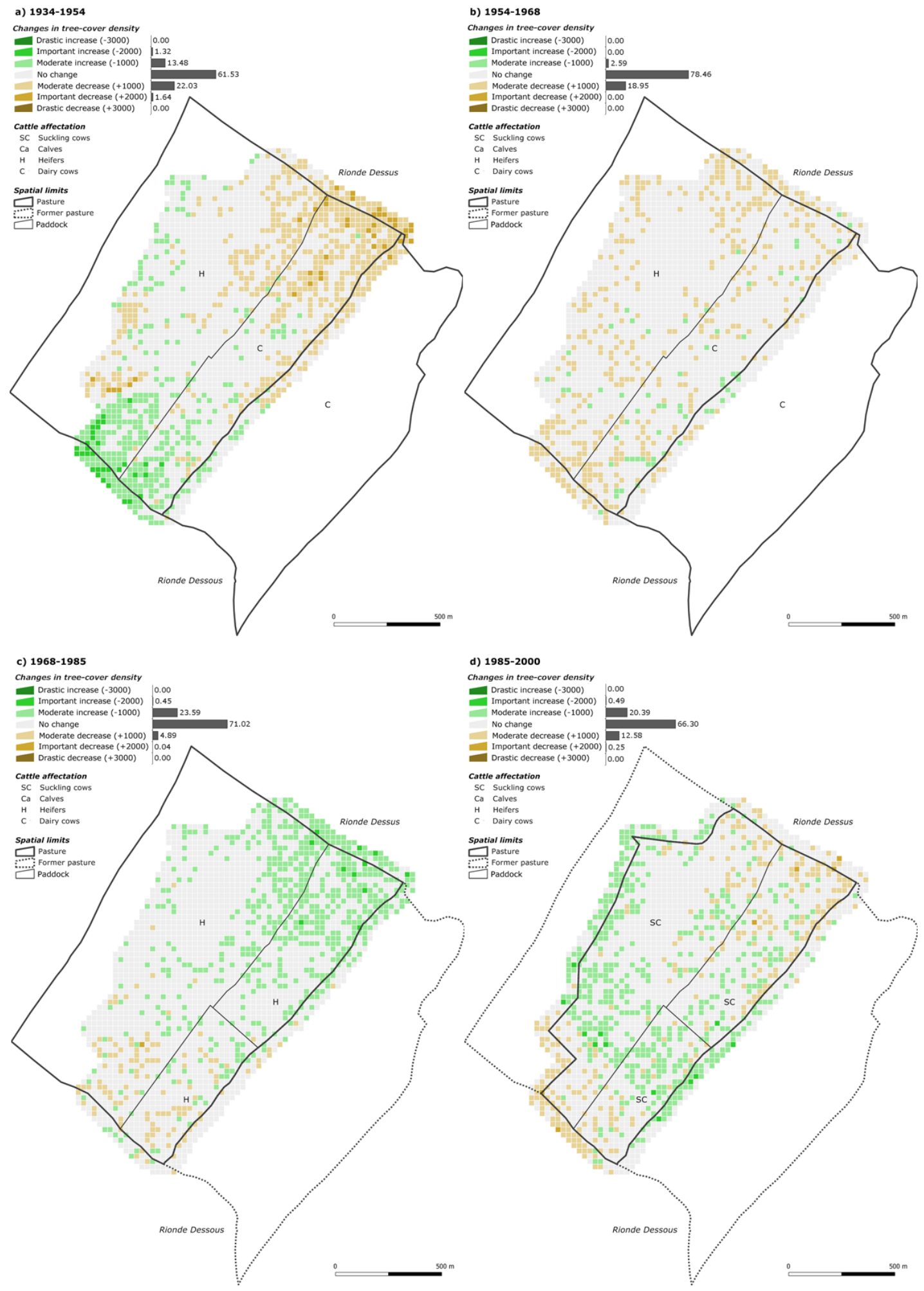


extensification in the long term. Indeed, the tree density decreased in the eastern sector of Les Planets between 1954 and 1968 (Fig. 5), in the area where trees previously propagated. Similarly, the western sector of Les Planets saw its tree cover decrease from 1968 onwards after a period of extensification. In the meantime, the forest higher up expanded downhill along the fence and partly invaded the eastern sector of Les Planets and the northern limit of Les Cluds.

\section{Marchairuz}

\section{Pasture chronicles}

Before 1936, the higher region of Rionde Dessus was managed together with the lower and more productive pasture of Rionde Dessous located in the southeast. According to one of the interviewees, six farmers took care of the 105 cows (105 LU) present in both pastures for 30 to 50 days each year. The milk produced on site was transformed by a cheese maker in Rionde Dessus and the cheese was ripened in Rionde Dessous. Wood exploitation was limited to the personal needs of the farmer and his family. According to the Forest Management Plan of 1916 (Commune de Marchissy 1916, Commune de Le Vaud 1916), the forest in Rionde was described as mature with few young stems and a disproportionately high number of large trees. The revision of the Forest Management Plan between 1935 and 1936 (Commune de Marchissy 1916, Commune de Le Vaud 1916) thus recommended increasing the harvesting potential, especially in the fertile valley, as well as the planting of young trees and the protection of them in other appropriate areas. In 1936, Rionde Dessus was divided into two paddocks (Fig. 7): the lower paddock was still used together with Rionde Dessous for summering the 105 cows (105 LU) whereas the larger upper paddock was designated for the breeding of 40 heifers (16 LU). Two major storms struck in the region in 1941 and 1946. These were followed by two drought episodes in 1945 and 1947. To give an idea of the importance of the resulting damages, more than $1300 \mathrm{~m}^{3}$ of wood was extracted in 1946 and 1947, while a total of $3000 \mathrm{~m}^{3}$ of wood was cut between 1935 and 1950, especially during World War II.

In 1965, the lower paddock of Rionde Dessus was divided into two paddocks (Fig. 7). The 105 cows (105 LU) that previously grazed there were all replaced by an all-heifer herd (40 LU), meaning the end of the local cheese production. As reported by one interviewee, this change was concomitant with the presence of a bovine disease (epizootic bovine abortion) and the difficulty of finding reliable people to breed cattle. Few forest interventions were realized between 1968 and 1985. In 1971, the Vallée de Joux region was affected by a major storm. A silvopastoral management plan was realized in 1980 and was set in motion over the following years. The size of the bigger paddock of Rionde Dessus was reduced in 1987 (Fig. 7) to restrict both cattle access and wood exploitation in the western forest stands as was previously recommended in the 1916 Forest Management Plan (Commune de Marchissy 1916,
Commune de Le Vaud 1916). In 1990, the new herd consisted of 47 suckling cows with their calves $(56.4 \mathrm{LU})$. That same year, the pasture was impacted by the storm Vivian.

Aerial image analysis

The relative repartition of the four different tree-cover classes in Rionde appears to be quite similar in 2000 to that in 1934 (Fig. 6). Before 1968, the trend showed a reduction of densely wooded pastures (3000) and grazed forests (4000). Between 1934 and 1954, sparsely wooded pastures (2000) consequently expanded as a result of the increased timber exploitation during war and wood damages due to the storms and drought episodes, whereas unwooded pastures (1000) remained constant. Between 1954 and 1968, unwooded pastures (1000) increased considerably at the expense of all other tree density categories, especially sparsely wooded pasture (2000). After 1968, the trend reversed: densely wooded pastures (3000) expanded linearly at the expense of unwooded (1000) and sparsely wooded pastures (2000). Grazed forests (4000) slightly increased in the same period.

Looking deeper into the spatial evolution allows us to localize where changes occurred. The 1934-54 evolution map (Fig. 7) shows a clear north-south pattern of the tree-cover evolution. A decrease in tree density is apparent in the areas along the borders of the cow paddock. In contrast to this, the southern part of the pasture shows a denser tree cover. Changes in tree density appear to be smaller and more scattered over the whole pasture between 1954 and 1968. The later period (1968 to 1985) reveals an inverted north-south tree-cover evolution pattern compared to that of war and postwar times. Trees appear to be denser with the notable exception of the southern zone. The tree propagation progressed towards the south during the most recent period of 1985 to 2000. Tree regeneration is also visible along the fence.

\section{DISCUSSION}

\section{Accuracy of the image analysis method}

The methodology presented for classifying historic aerial images of varying quality appears to be simple and effective for analyzing the dynamics of wooded pastures. Tree-cover classification is a suitable way to follow the landscape dynamics. Yet, it brings an incomplete view of the habitat and biodiversity changes given that these are not only determined by the evolution of the grassland-forest mosaic structure.

As long as images show a strong contrast in grayscale tones between trees and pasture, the method is adequate. The determination of the threshold $T$ is easy and reliable. However, images containing numerous fine-grained soil structures are trickier to handle. For instance, buildings, roads, and rock outcrops that appear in light tones induce biases in the grayscale tone distribution. Therefore, the method works best where the land-cover categories are limited to pasture and forest. The grayscale tone distribution is also greatly 
influenced by topography, camera orientation, and illumination conditions. Slope and aspect modify the luminance of the ground objects and can make it difficult to distinguish between different land-cover categories. Besides, the bigger the angle between the nadir and the orientation of the camera, the more the picture will show deformations and heterogeneous shadows. Finally, depending on the illumination of the terrain, the image contrast (luminosity effect) may not be sufficient to differentiate between trees and pasture from the grayscale tone distribution.

The grid resolution $(25 \times 25 \mathrm{~m})$ is considered to be the finest that can be used with the considered phytocoenosis classification. A finer grid would lead to erroneous interpretation of the soil cover. In cases where the cell size is smaller than the maximum size of a tree crown, some pixels would be classified as grazed forest when they actually represent a single tree in an open pasture. A too coarse grid would tend to average the proportion of pasture and trees, thus overestimating intermediate tree density classes, i.e., sparsely wooded pastures (2000) and densely wooded pasture (3000), leaving open and closed landscapes under-represented.

The tree-cover class adjustment to the structural types was made using the three parameters $L 1, L 2$, and $L 3$. Because of the contrasting heterogeneity between images, their value should be adapted separately for each image. An expert approach was required to visually set up the parameters as accurately as possible to obtain the most reliable classification. Though subject to interpretation, this stage brought a significant improvement and was relatively easily achieved by a trained ecologist.

Overall, the proposed semi-automated image processing method is a convenient way to compare aerial photographs of various periods and qualities. It is a much less time-consuming process than vectorization and is a more satisfactory approach than (semi)supervised classification. Despite its limitations, it is well adapted for the objective of the present study.

\section{Combining quantitative approaches with pastoral chronicles}

Land-cover changes obtained from the aerial image analyses were compared with the data describing the context in which the transformations occurred. Land-policy reforms and their socioeconomic effects are usually well described in official sources and literature. But while information regarding general driving forces such as regulations, subsidies, and prices is available at the national and regional levels together with basic statistics, local data for reconstructing the evolution of management practices are more difficult to obtain. Public offices and archives may possess valuable documents such as pasture and forest management plans to give insights on strategies and actions intended to utilize the land more rationally. However the history of the governance of mountain pastures has traditionally been recounted orally with only legal matters being put in writing. Thus, given the relative rarity of written documents, interviews are of central importance to widen the knowledge of wooded pasture management. A good understanding of the present situation is a prerequisite for reconstructing the past because it offers a comparison basis. Hence, current land managers were interviewed and they gave detailed descriptions of today's wooded pasture systems. Because most farmers succeeded their fathers and took over the domains, they also were able to give some information about past utilizations, like fence demarcations, livestock types, and cattle pressure. In addition, key persons constituting the living memory of both study regions supplemented the chronicles with their recollections of the past.

The reconstituted chronicles can be regarded as partial and subjective but they nevertheless delivered sufficient relevant information. Obviously it is not possible to document every practical change in the wooded pasture management evolution. However, the overall trend is more important than the short-term, small-scale specificities when we consider the 15-year time interval used in the land-cover analysis. Besides, the potential bias introduced by the personal views of the interviewees was limited by focusing on facts and crosschecking information. When memories were vague or hazy, approximations were sought with the actors.

Beside the incompleteness of the data, the main difficulty in combining quantitative data analysis with pastoral chronicles lies in the delay between the moment actions are taken and the moment responses are visible in space. Conversely, adjusting land policies and management practices to new observed spatial configurations may take time and extend over two time intervals. Not only are the responses slow, but their explanation is not always straightforward given the existing knowledge. For these reasons, it is sometimes difficult to track the cause-effect relationships.

Nevertheless, cross-analyzing spatial patterns and temporal dynamics of complex land systems with socioeconomic and biophysical processes brings value to the study of wooded pastures. And above all, such an approach can easily be repeated in other landscapes, provided that comparable data sets are available. Overall, it makes it possible, even with a small set of case studies, to identify important drivers of change and understand major land-use trends that are helpful for elaborating scenarios or simulation models (Peringer et al. 2013), in order to accurately inform decision making.

\section{Analysis of pasture-woodland dynamics}

The general evolution of the two studied pastures was basically influenced in the same way by major driving forces. Overall, the most important period of change for both pastures was between 1934 and 1954 with the lowest percentage values for the "no change" category (Fig. 5), with this trend being more pronounced in Rionde (Fig. 7). Transformations of great magnitude denoted a rapid landscape change. The demand for 
wood and food was high during the war and the years that followed, resulting in an intensive use of both wooded pastures. Moreover, the storms of 1941 and 1946, together with the drought episodes of 1945 and 1947, left the trees vulnerable to the propagation of the European spruce bark beetle (Ips typographus) in Rionde. These natural events emphasized the opening of the landscape, reflecting a tendency to get rid of damaged trees and old timbers where herbage was of best quality to contribute towards supplying wood during and shortly after wartime. Between 1954 and 1968, the effects of protectionist regulations, agricultural subsidies, and technical improvements that encouraged farmers to keep on using their pastures efficiently became more visible. Overall, this is the period when the least change occurred in both pastures. But while Rionde saw its tree cover continue to decrease rather homogeneously in space, the Bullet site showed the first signs of extensification with tree encroachment in some areas. After this, the trend generalized in both pastures, resulting in harsher conditions for wood and milk producers with the prices continually decreasing. Tree propagation in Rionde was only impeded slightly by the 1990 storm.

The more specific direction that each of the two pastures took during the observed decades is the result of local conditions and diverging management choices. The landscape of Rionde has been largely shaped by the natural events that occurred in the region at different periods. It is difficult to tell what the landscape would have been like without the storms and drought episodes because alternative land-use strategies would have been used in different conditions. Nevertheless, pasture and forest management have significantly influenced the local patterns of tree dynamics. Besides logging activities, managing the cattle behavior with fences and watering points strongly impacted the potential for tree regeneration (Kohler et al. 2006, Vandenberghe et al. 2006). Yet, extensification seems to have been difficult to avoid in the last 30 years of the twentieth century in Rionde.

The evolution of the pastures in Bullet relied on a spatial segregation process on two levels. First, it appeared that the closer the pastures were to the village, the more intensively they were used (Les Planets). Because of the need for new dwellings, some areas were even converted into building areas (Les Rasses). More distant pastures have been extensified with concomitant tree encroachment (Les Cluds) or even were abandoned (La Bullatonne). Secondly, in the most intensively used areas, the separation between pasture and forest tended to be sharper, like in Les Planets, as the result of rationalization strategies. Indeed, the evolution of the Bullet pastures is the result of an optimization process that was impacted little or not at all by natural events. The proximity of the village to which farmers and cattle went back every night makes a big difference compared to the summer pastures in Marchairuz.

\section{CONCLUSION}

The bipolar intensification/extensification dimension of change observed in the two case studies has manifold implications. Strictly speaking, the economic output of extensively used pastures is limited because their stocking capacity is suboptimal compared to intensively used pastures. Nevertheless, extensively used pastures also produce positive externalities. First, they allow more intensively used pastures, especially in lowlands, to rest and regenerate. Second, extensively used pastures still present a valuable landscape mosaic. Comparatively, the intensification process implies a loss of ecotones in the landscape. It has been shown that the landscape heterogeneity, induced by both geomorphological features (e.g., rocky outcrops) and by isolated and grouped trees, which in turn influence cattle activities, is a major factor for tree establishment and for enhancing biodiversity (Kohler et al. 2005, Smit et al. 2005, Dufour et al. 2006, Gillet et al. 2010). Still, the densely forested neighborhood or large forest patches increase the diaspore pressure on the extensively used pastures. Abandonment as well as over-utilization both involve risks in terms of land conservation. All these consequences illustrate fairly well the difficulty of managing wooded pastures regarding political, economical, and ecological stakes and keeping them in a sustainable equilibrium.

The important direct payment system of Switzerland compared to that of its neighboring countries allows the maintenance of an extensive pastoral economy. The planned increase of the summering contributions in 2012 makes the concerned Jura pastures even more valuable. The current low milk price leads to the breeding of suckling cows which require less work from the farmer because cows take care of their offspring and therefore do not need to be milked. This system imposes a high cattle pressure and thus allows little tree regeneration. While this might be a chance to preserve extensive pastures threatened by tree encroachment, adequate management structures and an appropriate cattle load are mandatory to avoid landscape segregation in more intensive areas.

Besides landscape and ecological services for which farmers are remunerated, and the growing-though difficult to quantify-importance of soft tourism, new environmental conditions such as a projected 3 to $4^{\circ} \mathrm{C}$ climate warming will have strong implications for land-use evolution (Briner et al. 2013, Buttler et al. 2012, Gavazov et al. 2013, Huber et al. 2012, 2013, Peringer et al. 2013) and are a major issue on the political agenda and for individual practices.

Responses to this article can be read online at: http://www.ecologyandsociety.org/issues/responses. $\mathrm{php} / 5287$ 


\section{Acknowledgments:}

This work was supported by the CCES (Competence Center Environment and Sustainability of the ETH Domain, Switzerland) as part of the Mountland project, and by the State Secretariat for Education and Research (SER C07.0112) in the framework of the COSTAction FP0603. The authors would like to thank Andi Rigling, Robert Huber, and all the persons who agreed to give interviews.

\section{LITERATURE CITED}

Antrop, M. 1997. The concept of traditional landscapes as a base for landscape evaluation and planning: the example of Flanders region. Landscape and Urban Planning 38:105-117. http://dx.doi.org/10.1016/S0169-2046(97)00027-3

Antrop, M. 2004. Landscape change and the urbanization process in Europe. Landscape and Urban Planning 67:9-26. http://dx.doi.org/10.1016/S0169-2046(03)00026-4

Aspinall, R. J., and M. J. Hill. 2008. Land use change: science, policy and management. CRC Press, Boca Raton, Florida, USA.

Braun, G. J., and M. D. Fairchild. 1999. Image lightness rescaling using sigmoidal contrast enhancement functions. Journal of Electronic Imaging 8(4):380-393.

Briner, S., C. Elkin, P. Bebi, and A. Grêt-Regamey. 2013. Trade-offs between ecosystem services in mountainous regions. Ecology and Society Vol. 18 in press.

Brodbeck, B. 2009. Producteurs suisses de lait (PSL). In Dictionnaire historique de la Suisse (DHS). Version 29/10/2009. [online] URL: http://www.hls-dhs-dss.ch/textes/ f/F42056.php.

Buttler A., K. Gavazov, A. Peringer, S. Siehoff, P. Mariotte, J.-B. Wettstein, J. Chételat, R. Huber, F. Gillet, and T. Spiegelberger. 2012. Conservation des pâturages boisés du Jura: défis climatiques et agro-politiques/ Erhaltung der Wytweiden im Jura: Klimatische und agrarpolitische Herausforderungen. Recherche Agronomique Suisse/ Agrarforschung 3(7-8):346-353.

Commune de Bassins. 1980. Plan d'aménagement sylvopastoral. Technical report. Canton de Vaud, Switzerland.

Commune de Bullet. 1928. Plan d'aménagement forestier / révisions en 1950, 1960, 1975, and 1992. Technical report. Canton de Vaud, Switzerland.

Commune de Bullet. 1964. Plan d'aménagement pastoral. Technical report. Canton de Vaud, Switzerland. Canton de Vaud, Switzerland.
Commune de Bullet. 1983. Plan d'aménagement sylvopastoral. Technical report. Canton de Vaud, Switzerland.

Commune de Le Vaud. 1916. Plan d'aménagement forestier /révisions en 1928-29 and 1935-36. Technical report. Canton de Vaud, Switzerland.

Commune de Marchissy. 1916. Plan d'aménagementforestier /révisions en 1928-29 and 1935-36. Technical report. Canton de Vaud, Switzerland.

Buttler, A., F. Kohler, and F. Gillet. 2009. The Swiss mountain wooded pastures: patterns and processes. Pages 377-396 in M. R. Mosquera-Losada, J. McAdam, and A. RigueiroRodriguez, editors. Agroforestry in Europe: current status and future prospects. Advances in Agroforestry Series, Volume 6. Springer Science and Business Media, The Netherlands. http:// dx.doi.org/10.1007/978-1-4020-8272-6 19

Dufour, A., Z. Gadallah, H. Wagner, A. Guisan, and A. Buttler. 2006. Plant species richness and environmental heterogeneity in a mountain landscape: effects of variability and spatial configuration. Ecography 29:573-584. http://dx.doi.org/10.1111/ j.0906-7590.2006.04605.x

Eichhorn, M. P., P. Paris, F. Herzog, L. D. Incoll, F. Liagre, K. Mantzanas, M. Mayus, G. Moreno, V. P. Papanastasis, D. J. Pilbeam, A. Pisanelli, and C. Dupraz. 2006. Silvoarable systems in Europe: past, present and future prospects. Agroforestry Systems 67:29-50. http://dx.doi.org/10.1007/ $\underline{\text { s10457-005-1111-7 }}$

Gallandat, J.-D., F. Gillet, E. Havlicek, and A. Perrenoud. 1995. PATUBOIS—typologie et systémique phyto-écologiques des pâturages boisés du Jura suisse. Technical report. Laboratoire d'écologie végétale et de phytosociologie, Institut de botanique, Université de Neuchâtel, Switzerland.

Ganskopp, D. 2001. Manipulating cattle distribution with salt and water in large arid-land pastures: a GPS/GIS assessment. Applied Animal Behaviour Science 73(4):251-262. http://dx. doi.org/10.1016/S0168-1591(01)00148-4

Gavazov, K., A. Peringer, A. Buttler, F. Gillet, and T. Spiegelberger. 2013. Dynamics of forage production in pasture-woodlands of the Swiss Jura Mountains under projected climate change scenarios. Ecology and Society 18 (1): 38. [online] URL: http://dx.doi.org/10.5751/ES-04974-180138.

Gillet, F., and J.-D. Gallandat. 1996. Integrated synusial phytosociology: some notes on a new, multiscalar approach to vegetation analysis. Journal of Vegetation Science 7 (1):13-18. http://dx.doi.org/10.2307/3236411

Gillet, F., F. Kohler, C. Vandenberghe, and A. Buttler. 2010. Effect of dung deposition on small-scale patch structure and seasonal vegetation dynamics in mountain pastures. 
Agriculture, Ecosystems, and Environment 135:34-41. http:// dx.doi.org/10.1016/j.agee.2009.08.006

Heady, H. F. 1949. Methods of determining utilization of range forage. Journal of Range Management 2(2):53-63. http://dx. doi.org/10.2307/3894543

Huber R., P. Bebi, S. Briner, H. Bugmann, A. Buttler, A. GrêtRegamey, C. Hirschi, R.W. Scholz, W. Zimmermann, and A. Rigling. 2012. MOUNTLAND: Changements climatiques et utilisation durable du sol en montagne/ MOUNTLAND: Klimawandel und nachhaltige Landnutzung im Berggebiet. Recherche Agronomique Suisse/ Agrarforschung 3(7-8):340-345.

Huber, R., S. Briner, A. Peringer, R. Seidl, S. Lauber, C. Hirschi, A. Widmer, F. Gillet, A. Buttler, and B. Q. Le. 2013. Modelling feedback effects between vegetation dynamics, farm structural change and policy development in the pasture woodlands of the Swiss Jura Mountains. Ecology and Society Vol. 18 in press.

Kohler, F., F. Gillet, J.-M. Gobat, and A. Buttler. 2005. Effect of cattle activities on gap colonisation in mountain pastures. Folia Geobotanica 41:289-304. http://dx.doi.org/10.1007/ BF02904943

Kohler F., F. Gillet, S. Reust, H. Wagner, F. Gadallah, J.-M. Gobat, and A. Buttler. 2006. Spatial and seasonal patterns of cattle habitat use in a mountain wooded pasture. Landscape Ecology 21:281-295. http://dx.doi.org/10.1007/s10980-005-0144-7

Krausman, F., H. Haberl, N. B. Schulz, K.-H. Erb, E. Darge, and V. Gaube. 2003. Land-use change and socio-economic metabolism in Austria-Part I: driving forces of land-use change: 1950-1995. Land Use Policy 20(1):1-20. http://dx. doi.org/10.1016/S0264-8377(02)00048-0

Kronert, R., J. Baudry, I. R. Bowler, and A. Reenberg (editors). 1999. Land-use changes and their environmental impact in rural areas in Europe. UNESCO, Paris, France.

Lambin, E. F., and H. G. Geist. 2006. Land-use and land-cover change: local processes and global impacts. Springer-Verlag, Berlin and Heidelberg, Germany.

Lambin, E. F., B. L. Turner, H. G. Geist, S. B. Agbola, A. Angelsen, J. W. Bruce, O. T. Coomes, R. Dirzo, G. Fischer, C. Folke, P. S. George, K. Homewood, J. Imbernon, R. Leemans, X. Li, E. F. Moran, M. Mortimore, P. S. Ramakrishnan, J. F. Richards, H. Skånes, W. Steffen, G. D. Stone, U. Svedin, T. A. Veldkamp, C. Vogel, and J. Xu. 2001. The causes of land-use and land-cover change: moving beyond the myths. Global Environmental Change 11(4):261-269. http://dx.doi.org/10.1016/S0959-3780(01)00007-3

Loi fédérale concernant la haute surveillance de la Confédération sur la police des forêts du 11 octobre 1902 (LFor); RS 921.0.
Loi fédérale sur l'amélioration de l'agriculture et le maintien de la population paysanne du 3 octobre 1951 (Loi sur l'agriculture); RS 910.1.

Loi fédérale du 29 avril 1998 sur l'agriculture (Loi sur l'agriculture, LAgr); RS 910.1.

Lyons, R. K., and R. V. Machen. 2001. Stocking rate: the key grazing management decision. Texas Agricultural Extension Service, Texas A\&M University System, College Station, Texas, USA.

Lyons, R. K., and R. V. Machen. 2002. Livestock grazing distribution: considerations and management. Texas Agricultural Extension Service, Texas A\&M University System, College Station, Texas, USA.

Moser, P. 2010. Elevage: XIXe et XXe siècles. In Dictionnaire historique de la Suisse (DHS). Version 04/03/2010. [online] URL: http://www.hls-dhs-dss.ch/textes/f/F26236.php.

Moser, P., and B. Brodbeck. 2007. Du lait pour tous: portrait en images, documents et analyses de l'économie et de la politique laitières en Suisse au 20e siècle. Hier + Jetzt, Verlag für Kultur und Geschichte, Baden, Switzerland.

Office Fédéral de l'Agriculture (OFAG). 1962-1974. Cadastre de la production agricole pour les communes de Marchissy, Le Vaud et Bullet. Bern, Switzerland.

Office Fédéral de l'Agriculture (OFAG). 1972. Cadastre alpestre de la commune de Bassins. Bern, Switzerland.

Office Fédéral de l'Agriculture (OFAG). 1974. Cadastre alpestre de la commune de Bullet. Bern, Switzerland.

Owens, M. K., K. L. Launchbaugh, and J. W. Holloway. 1991. Pasture characteristics affecting spatial distribution of utilization by cattle in mixed brush communities. Journal of Range Management 44(2):118-123. http://dx.doi. org/10.2307/4002308

Parker, J. R. 1997. Algorithms for image processing and computer vision. John Wiley \& Sons, New York, New York, USA.

Peringer, A., S. Siehoff, J. Chételat, T. Spiegelberger, A. Buttler, and F. Gillet. 2013. Past and future landscape dynamics in wooded pastures of the Jura Mountains under land-use and climate change. Ecology and Society Vol. 18 in press.

Plieninger, T., and M. Schaar. 2008. Modification of land cover in a traditional agroforestry system in Spain: processes of tree expansion and regression. Ecology and Society 13 (2):25. [online] URL: http://www.ecologyandsociety.org/ vol13/iss $2 /$ art25/. 
Rieben, E. 1957. La forêt et l'économie pastorale dans le Jura. $\mathrm{PhD}$ thesis. Ecole Polytechnique Fédérale, Zurich, Switzerland.

Roath, L. R., and W. C. Krueger. 1982. Cattle grazing and behavior on a forested range. Journal of Range Management 35(3):332-338. http://dx.doi.org/10.2307/3898312

Schuler, A. 2008. La loi sur les forêts et l'évolution au XXe siècle. In Dictionnaire historique de la Suisse (DHS). Version 31/03/2008. [online] URL: http://www.hls-dhs-dss.ch/textes/ f/F7849.php.

Service des forêts, de la faune et de la nature (SFFN). 2011. Eclairages sur les forêts du Canton de Vaud. Lausanne, Canton de Vaud, Switzerland.

Smit, C., D. Béguin, A. Buttler, and H. Müller-Schärer. 2005. Safe sites for tree regeneration: a case of associational resistance? Journal of Vegetation Science 16:209-214.

Stalder, H. 2009. Industrie laitière: XIXe et XXe siècles. In Dictionnaire historique de la Suisse (DHS). Version 20/08/2009. [online] URL: http://www.hls-dhs-dss.ch/textes/ f/F13952.php.

Stoddart, L. A. 1960. Determining correct stocking rate on range land. Journal of Range Management 13(5):251-255. http://dx.doi.org/10.2307/3895053

Taillefumier, F., and H. Piégay. 2003. Contemporary land use changes in prealpine Mediterranean mountains: a multivariate GIS-based approach applied to two municipalities in the Southern French Prealps. CATENA 51(3-4):267-296. http:// dx.doi.org/10.1016/S0341-8162(02)00168-6

Tanner, A. 2011. Plan Wahlen. In Dictionnaire historique de la Suisse (DHS). Version 25/01/2011. [online] URL: http:// www.hls-dhs-dss.ch/textes/f/F13783.php.

Turner, B. L., and W. B. Meyer. 1994. Global land-use and land-cover change: an overview. Pages 3-10 in W. B. Meyer, and B. L. Turner, B. L., editors. Changes in land use and land cover: a global perspective. Cambridge University Press, Cambridge, Maine, USA.

Vandenberghe, C., F. Freléchoux, Z. Gadallah, and A. Buttler. 2006. Competitive effects of herbaceous vegetation on tree seedling emergence, growth and survival:does gap size matter? Journal of Vegetation Science 17:481-488.

Verburg P. H., J. R. R. van Eck, T. C. M. de Nijs, M. J. Dijst, and P. Schot. 2004. Determinants of land-use change patterns in the Netherlands. Environment and Planning B: Planning and Design 31(1)125-150. http://dx.doi.org/10.1068/b307

WorldClim - Global Climate Data. 2005. Data for current conditions ( 1950-2000). [online] URL: http://www. worldclim.org/current. 